\title{
Nurmiheinien ensimmäisen sadon sulavuuden ja sadon määrän mallit nurmirehuntuotannon hallintaan
}

\author{
Marketta Rinne ${ }^{1)}$, Timo Pitkänen ${ }^{1)}$, Laura Nyholm ${ }^{2)}$, Juha Nousiainen ${ }^{2)}$ ja Pekka Huhtanen ${ }^{3)}$ \\ ${ }^{1)}$ MTT (Maa-ja elintarviketalouden tutkimuskeskus), 31600 Jokioinen, etunimi.sukunimi@mtt.fi \\ ${ }^{2)}$ Valio Oy, Alkutuotanto, PL 10,00039 Valio, etunimi.sukunimi@valio.fi \\ ${ }^{3)}$ Ruotsin Maatalousyliopisto (SLU), S-90183 Uumaja, Ruotsi, etunimi.sukunimi@njv.slu.se
}

\section{Tiivistelmä}

Suomen olosuhteissa nurmikasvien kehitys alkukesällä on erittäin nopeaa. Korjuun ajoitus on rehuntuotannon taloudelliseen tulokseen merkittävästi vaikuttava päätös, sillä kasvun edetessä rehun sulavuus laskee, mutta sadon määrä kasvaa. Sulavuuden arviointi kasvustosta ei ole kovin helppoa ja vuosittaiset vaihtelut sopivan korjuuajan saavuttamisessa ovat suuria alkukesän vaihtelevista sääoloista johtuen. Esittämällä D-arvon muutos suhteessa lämpösummaan on pystytty avustamaan viljelijöitä korjuuaikapäätöksen tekemisessä. Ennusteet on esitetty MTT:n ja Valio Oy:n yhteisessä ARTTURI ${ }^{\circledR}$ verkkopalvelussa (www.mtt.fi/artturi). Tämän työn tarkoituksena on tarkentaa alkukesän nurmikasvien D-arvoennustetta kehittämällä taustalla käytettävää mallia. Lisäksi tarkasteltiin, mitkä säätekijät vaikuttavat nurmien kuiva-ainesadon kehittymiseen.

D-arvoa mallitettiin yleisillä lineaarisilla sekamalleilla käyttäen perustana Gompertzin käyrää muistuttavaa yhtälöä ja kuiva-ainesatoa mallitettiin lineaarisilla sekamalleilla. Sarjakohtaisia selittäjiä aineistossa olivat mm. maalaji, sijainti, kasvukautta edeltäneet lämpösumma ja sadesumma sekä niiden johdannaiset. Havaintokohtaisina selittäjinä lämpösumman lisäksi käytettiin eri sääsuureita ja kasvuajan pituutta kasvukauden alusta. D-arvot vaihtelivat sarjoissa kasvukauden aikana välillä 510 - 786 $\mathrm{g} / \mathrm{kg}$ ka keskiarvon ollessa $710 \mathrm{~g} / \mathrm{kg}$ ka. D-arvon ennustamisessa päädyttiin seuraavaan malliin: D-arvo $(\mathrm{g} / \mathrm{kg} \mathrm{ka})=769.5-\exp (5.61 \times(1-\exp (-0.07 \times(\mathrm{LS}+0.016 \times$ PreLS28 -7.58) $)))$, missä LS on kasvukauden lämpösummakertymä astepäivinä $\left({ }^{\circ} \mathrm{C}\right.$ vrk) ja PreLS28 on kasvukautta edeltävän 28 päivän keskilämpötilojen summa $\left(\mathrm{R}^{2}=0.82\right)$. Kuiva-ainesadot hehtaaria kohden vaihtelivat välillä $500 \mathrm{~kg}-11$ 000 kg keskiarvon ollessa 4200 kg/. Kuiva-aineen hehtaarisato lisääntyi keskimäärin 191 kg/pv kasvun edetessä alkukesällä.

Nurmisadon D-arvon lasku alkukesällä on hyvin nopeaa ja varsin johdonmukaista. D-arvon muutos on käyräviivaista, mutta säilörehun korjuuaikaan sen on varsin lineaarista ja keskimäärin 5 g/kg ka päivässä. Lämpösummaa käyttäen D-arvon kehityksestä voidaan antaa kohtuullisia yleisiä ennusteita. Lämpö-olot vaikuttivat merkitsevästi myös kuiva-ainesadon kertymiseen, mutta sadesumma ei. Kasvustokohtaiset erot olivat erittäin suuria joten kuiva-ainesatoennusteet voivat olla ainoastaan suuntaa-antavia.
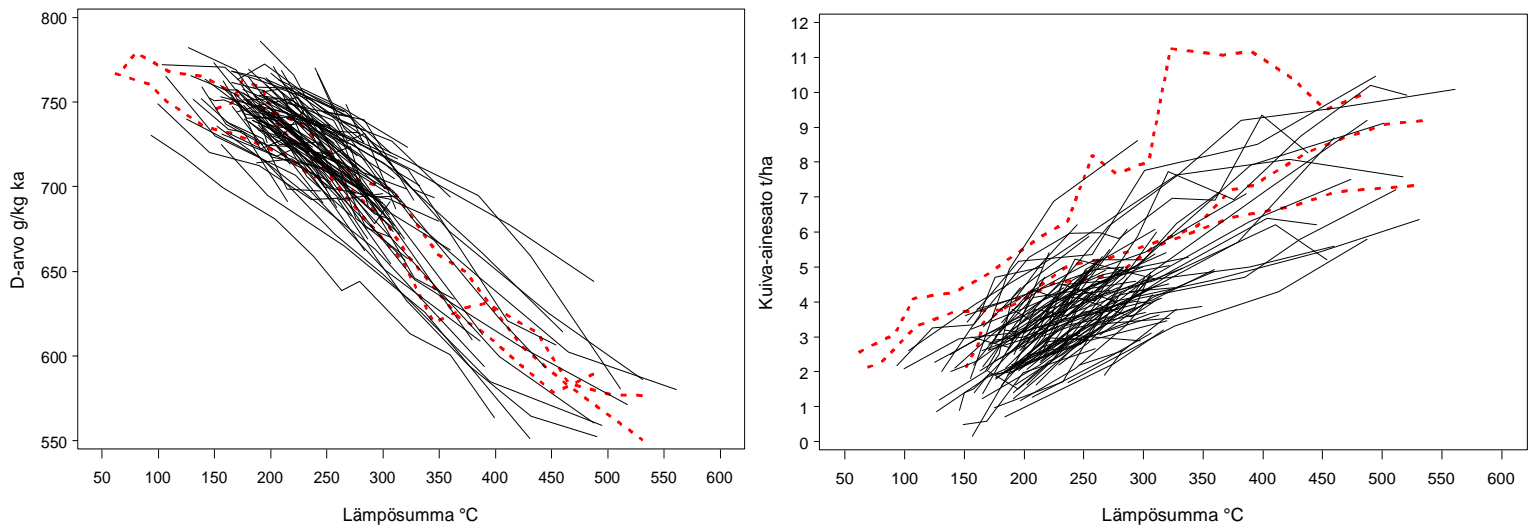

Kuva. Korjuuaika-aineiston nurmikasvustojen D-arvon lasku (g/kg ka; vas.) ja sadon (kg ka/ha, oik.) kasvu lämpösumman kertyessä alkukesällä siten, että saman kasvuston havainnot on yhdistetty toisiinsa viivalla (näytteitä 430 ja sarjoja 101). Jokioisten ns. pitkät sarjat on merkitty kuvaan katkoviivalla.

Asiasanat: nurmi, sulavuus, D-arvo, sato, säilörehu, korjuuaika, kehitysvaihe, lämpösumma, mallinnus, kasvumalli 


\section{Johdanto}

Nurmirehut muodostavat keskimäärin 54 \% lypsylehmien rehuannoksen energiasta (ProAgria 2009). Suomen olosuhteissa nurmikasvien kehitys alkukesällä on erittäin nopeaa. Korjuun ajoitus on rehuntuotannon taloudelliseen tulokseen merkittävästi vaikuttava päätös, sillä kasvun edetessä rehun sulavuus laskee, mutta sadon määrä kasvaa. Sulavuus vaikuttaa rehun energia- ja valkuaisarvoihin ja syöntipotentiaaliin (Rinne ym. 2008a) eli rehun tuotantovaikutukseen. Esimerkiksi lypsylehmien maitotuotos pienenee keskimäärin 0.5 kg päivässä, kun rehun D-arvona ilmaistu sulavuus laskee 1 \%yksikön (Rinne 2000). Alkukesällä tämä tapahtuu tyypillisesti kahdessa päivässä. Sadon määrällä puolestaan on merkittävä vaikutus rehun hintaan ja rehujen riittävyyteen karjan ruokinnassa tai toisaalta tarvittavaan rehuntuotantopinta-alaan.

Sulavuuden arviointi kasvustosta ei ole kovin helppoa ja vuosittaiset vaihtelut sopivan korjuuajan saavuttamisessa ovat suuria alkukesän vaihtelevista sääoloista johtuen. Esittämällä D-arvon muutos suhteessa lämpösummaan on pystytty avustamaan viljelijöitä korjuuaikapäätöksen tekemisessä. Ennusteet on esitetty MTT:n ja Valio Oy:n yhteisessä ARTTURI ${ }^{\circledR}$-verkkopalvelussa (www.mtt.fi/artturi).

Tämän työn tarkoituksena on tarkentaa alkukesän nurmikasvien D-arvoennustetta kehittämällä taustalla käytettävää mallia. Lisäksi tarkasteltiin, mitkä säätekijät vaikuttavat nurmien kuiva-ainesadon kehittymiseen.

\section{Aineisto ja menetelmät}

Nurmikasvustojen kehityksestä alkukesällä kerättiin ns. korjuuaikanäytteet (101 sarjaa 61 eri paikkakunnalta, yhteensä 430 näytettä vuosilta 1996-2006). Lisäksi MTT Jokioisilta kerättiin ns. pitkät nurminäytesarjat (17 näytettä v.1996, 13 näytettä v. 1997 ja 16 näytettä v. 1998). Valtaosan korjuuaikanäytteistä muodostavat Valio Oy:n keräämät näytteet, joiden tulokset on julkaistu ensimmäisen säilörehusadon korjuun alla osana ARTTURI ${ }^{\circledR}$-verkkopalvelun Korjuuaikatiedotusta. Lisäksi mukana on MTT:n koepaikoilta kerättyjä näytesarjoja. Kultakin paikkakunnalta otettiin mukaan vain yksi näytesarja. Kasvupaikan maalaji rekisteröitiin karkealla jaolla lämpimiin (hiekka ja hietamaat) tai kylmiin maihin (multa- ja turvemaat). Näytteenottopaikat ovat valtakunnallisesti jakautuneet suhteellisen tasaisesti noin Oulun korkeudelle asti, mutta Lapista on vain vähän näytteitä (kuva 1).

Kasvustot olivat pääsääntöisesti 2. satovuoden timotei-nurminataseoksia, jotka olivat saaneet lannoitetyppeä noin 100 kg/ha keväällä. Näytteet kerättiin 1-2 kertaa viikossa kehikkomenetelmällä (vähintään 4 osanäytettä kasvustosta, joista jokainen $0,25 \mathrm{~m}^{2}$ ) pääasiassa ennen varsinaista korjuuaikaa. Kuiva-ainesato määritettiin kerätyn näytteen painon perusteella. MTT:n Jokioisten Lintupajun tilalta kerättiin kehikkomenetelmällä pitempiä sarjoja vastaavien nurmikasvustojen kehityksestä, jotta myös hyvin varhaisesta ja myöhäisestä kasvuvaiheesta saatiin aineistoa. Säätiedot perustuvat Ilmatieteen laitoksen mittauksiin ja kerättiin näytteenottopaikkaa lähimmältä sääasemalta, jonka säätiedot olivat MTT:n käytettävissä. Yleisesti käytettyjen lämpösumman (LS, raja-arvona $+5^{\circ} \mathrm{C}$ ) ja sadesumman lisäksi laskettiin lämpösumma 14 tai 28 vrk ajalta ennen kasvukauden alkua (PreLS14 ja PreLS28). Molemmat näyteaineistot on kuvailtu taulukossa 1.

Näytteiden sulavuus analysoitiin pepsiini-sellulaasimenetelmällä (Nousiainen ym. 2003) Valion tai MTT:n laboratoriossa. Näytteen D-arvo laskettiin kertomalla näytteen orgaanisen aineen (OA) pitoisuus (1000 - tuhkapitoisuus, g/kg ka) OA:n sulavuudella (OAS). Näytteet analysoitiin pääasiassa Valion laboratoriossa mutta MTT:n näyteet MTT:llä. Valiolla määritetyt sellulaasiliukoisuudet korjattiin vastaamaan MTT:n määrityksiä kaavalla:

Liukoisuus $_{\text {MTT }}=29.9+\left(0.989 \times\right.$ Liukoisuus $\left._{\text {Valio, }}, \mathrm{g} / \mathrm{kg} \mathrm{OA}\right)$.

Sellulaasiliukoisuus (OMS) täytyy muuttaa vastaamaan näytteen in vivo -sulavuutta käyttäen empiiristä korjausyhtälöä sellulaasiliukoisuuden ja in vivo -sulavuuden välisestä yhteydestä. Tätä tarkastelua varten laskettiin käyräviivainen yhteys ruohonäytteiden sellulaasiliukoisuuden (HOMS, g/kg OA) ja säilörehun pässeillä määritteyn in vivo -sulavuuden (aineisto kuvailtu Huhtasen ym. (2005) artikkelissa) välille:

Säilörehun OAS $(\mathrm{g} / \mathrm{kg} \mathrm{OA})=-721.33+2.8034 \times$ HOMS $-0.00120 \times \mathrm{HOMS}^{2}$

Kuvassa 2 on havainnollistettu lineaarisia säilörehun ja raaka-aineen korjausyhtälöiden ja käyräviivaisen raaka-aineen korjausyhtälön vaikutusta säilörehun D-arvoon. Raaka-aineen kaava antaa kautta linjan matalampia sulavuusarvoja, mikä perustuu siihen, että säilönnän aikana tapahtuu väistämättä sulavien ravintoaineiden tappioita, jolloin sulavuus hieman heikkenee (Huhtanen ym. 2005). Kaavan 
käyräviivaisuus antaa hyvin sulaville näytteille hieman lineaarista yhtälöä matalampia arvoja, jotka ovat biologisesti uskottavampia. Kun rehunäytteen OMS on hyvin korkea, sen nousu parantaa in vivo sulavuutta vähenevästi.

Säilörehun D-arvo ei voi teoriassakaan olla juuri yli $760 \mathrm{~g} / \mathrm{kg}$ ka. Taulukkoon 2 on laskettu esimerkki D-arvon muodostumisesta käyttäen lähtöarvoina suomalaisista nurmiheinäkasvustoista erittäin varhaisessa ja myöhäisessä kehitysvaiheessa havaittuja arvoja (Huhtanen ym. 2006, Rinne ym. 2008b). Nurmen sulavuuteen vaikuttavat kuidun ja sulamattoman kuidun pitoisuudet ja potentiaalisesti sulavan kuidun sulavuus. Näiden lähtötietojen perusteella voidaan laskea D-arvo.

Päädyimme käyttämään näytteiden sulavuuden laskennassa käyräviivaista ruohon sellulaasiliukoisuudesta säilörehun sulavuuden ennustavaa yhtälöä. Se antoi vähemmän epärealistisen korkeita D-arvoja kuin muut yhtälöt. Korjuuaikapäätöstä tehtäessä kiinnostavaa on nimenomaan se, mikä on korjatun rehun D-arvo eikä niinkään pellolla kasvavan nurmen.

D-arvoa mallitettiin yleisillä lineaarisilla sekamalleilla käyttäen perustana Gompertzin käyrää muistuttavaa yhtälöä (Thornley \& France 2007), jonka perusmuoto sarjan i havainnolle j on:

D-arvo, g/kg ka $a_{i j}=a-\exp \left(b_{i} \times\left(1-\exp \left(c_{i} \times\left(L S+d_{i j}\right)\right)\right)+e_{i j}\right.$, missä a, b, c ja d ovat mallin parametreja, LS on lämpösumma ja $e_{i j}$ virhetermi. Parametri a kuvaa Darvon ylärajaa, exp(b) on ylärajan ja alarajan välinen ero, c on lämpösumman vaikutuksen kulmakerroin ja d lämpösumman siirtoparametri. Kutakin parametria mallitettiin joko sarjoittain tai havainnoittain vaihtelevilla selittäjillä. Mallituksessa alarajaa b ja kulmakerrointa c mallitettiin sarjakohtaisilla selittäjillä ja lämpösumman siirtoa sarja- ja havaintokohtaisilla selittäjillä. Parametrien a, b ja d sallittiin vaihdella myös satunnaisesti sarjoittain. Sarjakohtaisia selittäjiä aineistossa olivat mm. maalaji, sijainti, kasvukautta edeltäneet lämpösumma ja sadesumma sekä niiden johdannaiset. Havaintokohtaisina selittäjinä lämpösumman lisäksi käytettiin eri sääsuureita ja kasvuajan pituutta kasvukauden alusta.

Kuiva-ainesatoa mallitettiin lineaarisilla sekamalleilla pääsääntöisesti samoja selittäjiä käyttäen kuin D-arvon kohdalla. Mallissa oli kiinteiden vaikutuksen lisäksi sarjakohtainen satunnainen lämpösumman tai kasvukauden pituuden kulmakerroin sekä satunnainen sarjakohtainen vakiotermi.

Mallituksien aikana eri selittäjiä ja niiden yhdysvaikutuksia mallissa jo olevien selittäjien kanssa lisättiin malliin yksi kerrallaan ja kunkin selittäjän tarpeellisuutta tarkasteltiin selittäjien p-arvojen avulla. Molempien vasteiden mallituksen aikana mallin oletuksien voimassaoloa tarkasteltiin erilaisten jäännöskuvien ja tunnuslukujen avulla. Mallien parametrit estimoitiin käyttäen suurimman uskottavuuden menetelmää. Mallien selittämää vaihtelua kuvattiin keskimääräisen sarjan selitysasteella (Vonesh ym. 1997), joka samalla kuvaa mallin käyttökelpoisuutta ennustetarkoitukseen. Lisäksi eri mallien paremmuutta vertailtiin käyttäen mm. Akaiken informaatiokriteeriä (AIC) ja jäännösvirheen hajontaa.

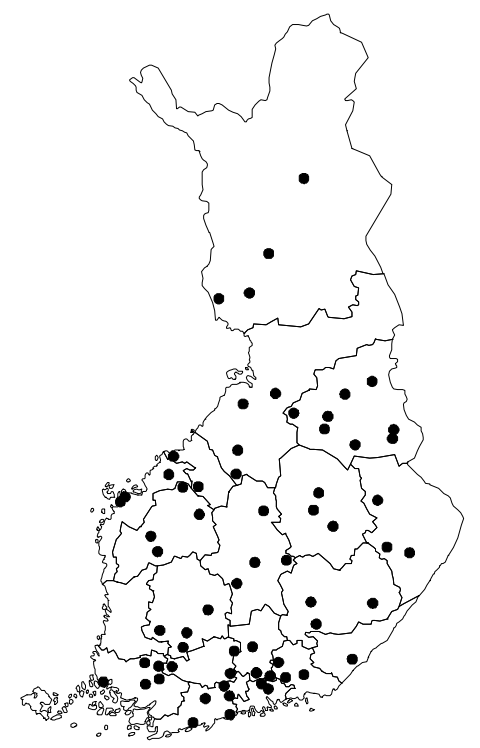

Kuva 1. Nurminäytteiden näytteenottopaikkoja on melko tasaisesti Oulun korkeudelle asti. 


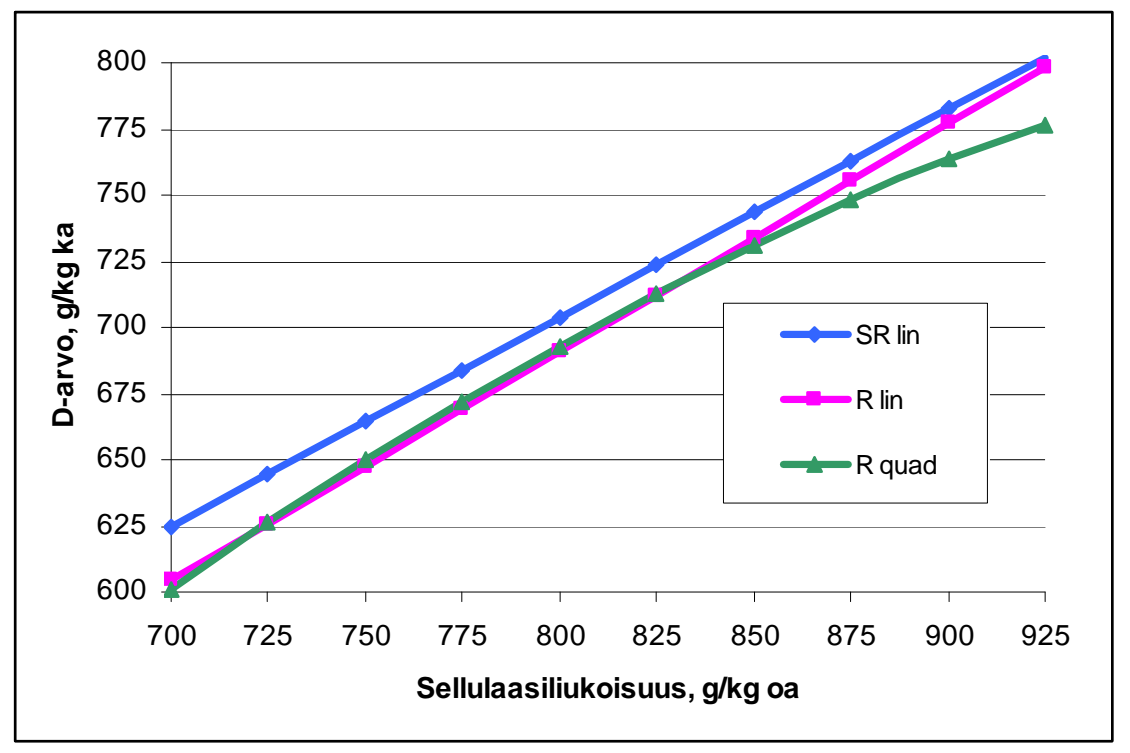

Kuva 2. Sellulaasiliukoisuudesta eri kaavoilla laskettu D-arvo. Kaavoilla lasketaan ensin orgaanisen aineen sulavuus ja D-arvot kaavioon on laskettu käyttäen vakiotuhkapitoisuutta 80 g/kg kuiva-ainetta. Käytetyt kaavat ovat säilörehun sellulaasiliukoisuudesta lineaarisella yhtälöllä laskettu säilörehun Darvo (SR lin, Huhtanen ym. 2006), ruohonäytteen sellulaasiliukoisuudesta lineaarisella yhtälöllä laskettu säilörehun sulavuus (R lin, Huhtanen ym. 2005) ja ruohonäytteen sellulaasiliukoisuudesta toisen asteen käyräviivaisella yhtälöllä laskettu säilörehun sulavuus (R quad, julkaisematon perustuen Huhtasen ym. (2005) artikkelissa kuvaamaan aineistoon).

Taulukko 1. Nurminäyteaineistojen kuvailu.

\begin{tabular}{|c|c|c|c|c|c|c|c|c|}
\hline & \multicolumn{4}{|c|}{ Koko nurminäyteaineisto $^{1)}$} & \multicolumn{4}{|c|}{ Jokioisten pitkät sarjat $^{2)}$} \\
\hline & $\begin{array}{l}\text { Keski- } \\
\text { arvo }\end{array}$ & $\begin{array}{l}\text { Keski- } \\
\text { hajonta }\end{array}$ & Minimi & Maksimi & $\begin{array}{c}\text { Keski- } \\
\text { arvo }\end{array}$ & $\begin{array}{l}\text { Keski- } \\
\text { hajonta }\end{array}$ & Minimi & Maksimi \\
\hline Kasvuaika, pv & 47.5 & 12.2 & 9.0 & 81.0 & 45.5 & 17.5 & 9.0 & 81.0 \\
\hline Lämpösumma, ${ }^{\circ} \mathrm{C}$ vrk & 254 & 87.7 & 49 & 561 & 278 & 139.0 & 49 & 539 \\
\hline Keskilämpötila, ${ }^{\circ} \mathrm{C}$ & 10.1 & 1.1 & 6.5 & 13.4 & 10.6 & 1.2 & 8.2 & 13.4 \\
\hline Sadesumma, mm & 70 & 40.7 & 0.0 & 218 & 91 & 57.0 & 14 & 218 \\
\hline PreLS14, ${ }^{\circ} \mathrm{C}$ vrk ${ }^{3)}$ & 32.0 & 18.6 & -4.2 & 77.8 & 38.5 & 25.7 & 4.3 & 62.0 \\
\hline PreLS28, ${ }^{\circ} \mathrm{C}$ vrk $^{3)}$ & 35.7 & 53.6 & -81.8 & 153.3 & 52.2 & 57.9 & -19.1 & 116.1 \\
\hline $\mathrm{OAS}^{4)}, \mathrm{g} / \mathrm{kg} \mathrm{OA}$ & 768 & 59.9 & 542 & 846 & 739 & 83.4 & 586 & 846 \\
\hline D-arvo, g/kg ka & 710 & 51.4 & 510 & 786 & 684 & 69.5 & 551 & 779 \\
\hline Tuhka, g/kg ka & 75.0 & 11.4 & 44.2 & 108.0 & 72.3 & 12.3 & 51.3 & 95.4 \\
\hline Raakavalk., g/kg ka & 186 & 49.5 & 77 & 321 & 169 & 67.2 & 86 & 321 \\
\hline Kuitu, g/kg ka & 550 & 86.3 & 350 & 717 & 579 & 100.9 & 407 & 717 \\
\hline Kasvuston korkeus, cm & 53 & 17.3 & 15 & 115 & 54 & 23.7 & 15 & 98 \\
\hline Sato, kg ka/ha & 4103 & 1962 & 160 & 11259 & 6016 & 2651 & 2125 & 11259 \\
\hline
\end{tabular}

${ }^{1)}$ Sarjoja109 kpl, näytteitä 462 kpl, huom. aineisto sisältää myös Jokioisten pitkät sarjat

${ }^{2)}$ Sarjoja 3 kpl, näytteitä $46 \mathrm{kpl}$

${ }^{3)}$ Vuorokauden keskilämpötilojen summa 14 tai 28 vrk ennen kasvukauden alkua

${ }^{4)}$ Orgaanisen aineen sulavuus 
Taulukko 2. Kaavamainen laskelma nurmirehujen D-arvon muodostumisesta ja Suomen olosuhteissa timotei-nurminatakasvustoille tyypillisistä maksimi- ja minimiarvoista.

\begin{tabular}{|c|c|c|c|c|c|}
\hline \multirow{2}{*}{ Ominaisuus } & \multirow{2}{*}{ Lyhenne } & \multirow{2}{*}{ Menetelmä } & \multirow{2}{*}{ Yksikkö } & \multicolumn{2}{|c|}{ Ruohon kehitysvaihe $^{1)}$} \\
\hline & & & & Aikainen & Myöhäinen \\
\hline Tuhkapitoisuus & tuhka & Määritetty & $\mathrm{g} / \mathrm{kg} \mathrm{ka}$ & 85 & 70 \\
\hline $\begin{array}{l}\text { Orgaaniseen aineen pitoi- } \\
\text { suus }\end{array}$ & OA & = kuiva-aine - tuhka & $\mathrm{g} / \mathrm{kg} \mathrm{ka}$ & 915 & 930 \\
\hline $\begin{array}{l}\text { Solunseinäkuidun pitoisuus } \\
\text { neutraalidetergenttimene- } \\
\text { telmällä }\end{array}$ & kuitu & Määritetty & $\mathrm{g} / \mathrm{kg} \mathrm{ka}$ & 400 & 650 \\
\hline $\begin{array}{l}\text { Sulamattoman kuidun } \\
\text { pitoisuus }\end{array}$ & iNDF & Määritetty & g/kg ka & 20 & 160 \\
\hline $\begin{array}{l}\text { Potentiaalisesti sulavan } \\
\text { kuidun sulavuus }\end{array}$ & pdNDFD & Määritetty & g/g & 0.90 & 0.80 \\
\hline $\begin{array}{l}\text { Ruoansulatuskanavassa } \\
\text { sulamatta jäänyt kuitu }\end{array}$ & uNDF & $\begin{array}{c}=\text { sulamaton kuitu }+(1- \\
\text { pdNDFD }) \times \text { kuitu }\end{array}$ & $\mathrm{g} / \mathrm{kg} \mathrm{ka}$ & 60 & 290 \\
\hline Kuidun sulavuus & NDFD & $=($ kuitu - uNDF $) /$ kuitu & $\mathrm{g} / \mathrm{g}$ & 0.85 & 0.55 \\
\hline $\begin{array}{l}\text { Solunsisällysaineiden pitoi- } \\
\text { suus }\end{array}$ & NDS & = kuiva-aine - tuhka - kuitu & $\mathrm{g} / \mathrm{kg} \mathrm{ka}$ & 515 & 280 \\
\hline $\begin{array}{l}\text { Solunsisällysaineiden nä- } \\
\text { ennäinen sulavuus }\end{array}$ & NDSD & $\left.=(1.015 \times \mathrm{NDS}-101) / \mathrm{NDS}^{2}\right)$ & $\mathrm{g} / \mathrm{g}$ & 0.82 & 0.65 \\
\hline $\begin{array}{l}\text { Orgaanisen aineen sula- } \\
\text { vuus (näennäinen) }\end{array}$ & OAS & $\begin{aligned}= & (\mathrm{kuitu} / \mathrm{OA}) \times \mathrm{NDFD}+ \\
& (\mathrm{NDS} / \mathrm{OA}) \times \mathrm{NDSD}\end{aligned}$ & $\mathrm{g} / \mathrm{g}$ & 0.83 & 0.61 \\
\hline $\begin{array}{l}\text { Sulavan orgaanisen aineen } \\
\text { pitoisuus kuiva-aineessa }\end{array}$ & D-arvo & $=\mathrm{OAS} \times \mathrm{OA}$ & $\mathrm{g} / \mathrm{kg} \mathrm{ka}$ & 762 & 568 \\
\hline
\end{tabular}

${ }^{1)}$ Käytetyt esimerkkiarvot perustuvat suomalaiseen nurmien kehitystä selvittäneeseen koesarjaan (Huhtanen ym. 2006, Rinne ym. 2008b).

${ }^{2)}$ Solunsisällysaineiden sulavuus laskettu Lucasin yhtälön periaatteen mukaisesti siten että niiden todellinen sulavuus on täydellistä ja sonnan metabolista ja endogeenista ainetta muodostuu n. $100 \mathrm{~g} / \mathrm{kg}$ syötyä kuivaainekiloa kohti (Huhtanen ym.2006)

\section{Tulokset ja niiden tarkastelu}

\section{D-arvo}

Näytteiden D-arvon lasku kasvun edetessä alkukesällä on esitetty kuvassa 3. D-arvot vaihtelivat sarjoissa kasvukauden aikana välillä 510 - 786 g/kg ka keskiarvon ollessa 710 g/kg ka. D-arvon ennustamisessa päädyttiin seuraavaan malliin:

D-arvo $(\mathrm{g} / \mathrm{kg} \mathrm{ka})=769.5-\exp (5.61 \times(1-\exp (-0.07 \times(\mathrm{LS}+0.016 \times$ PreLS28 -7.58$)))))$,

missä LS on kasvukauden lämpösummakertymä astepäivinä ( ${ }^{\circ} \mathrm{C}$ vrk) ja PreLS28 on kasvukautta edeltävän 28 päivän keskilämpötilojen summa $\left(\mathrm{R}^{2}=0.82\right)$.

Mallin perusteella keskimääräisen sarjan D-arvon yläraja on $769.5 \mathrm{~g} / \mathrm{kg}$ ka ja se laskee lämpösumman kasvaessa noin 496 g/kg ka:han (769.5 - exp(5.61)). Alarajaa ei kuitenkaan voida tämän aineiston perusteella estimoida kovin tarkasti, sillä riittävän pitkiä näytesarjoja ei ole tarpeeksi. Darvon kehityksen käyräviivaisuutta mallinnettiin erikseen pelkästään Jokioisten kolmea pitkää sarjaa käyttäen ja D-arvon laskun hidastuminen tarkastelujakson loppupuolella on selvemmin havaittavissa pitkien sarjojen perusteella estimoidussa mallissa. Jokioisten pitkien sarjojen avulla alarajan estimaatiksi saatiin $532 \mathrm{~g} / \mathrm{kg}$ ha.

Kuvassa 4 koko Artturi-aineiston ja pitkien käyrien mallit on esitetty samassa kuvassa. Kasvun alkuvaiheessa D-arvon lasku on hidasta ja nopeutuu tyypilliseen säilörehun korjuuaikaan. Sen jälkeen D-arvon lasku hidastuu, kun kasvit alkavat saavuttaa kypsyyden. D-arvon tasaantumista ei pystytty koko aineistoon perustuvalla mallilla kovin hyvin osoittamaan, koska kasvustoista ei siinä vaiheessa enää jatkettu näytteiden ottoa. Lisäksi uudet versot alkavat kasvaa vanhan kasvuston läpi, mikä häiritsisi tulosten tulkintaa. 
D-arvon lasku on varsin johdonmukaista kasvun edetessä, mutta käytetyillä selittäjillä ei pystytty kovin hyvin hallitsemaan sarjojen välistä tasoeroa. Tilakohtaisen D-arvoennusteen tarkentamiseksi on mahdollista analysoida nurminäyte ennen korjuuaikaa ja käyttää D-arvotulosta "kalibroimaan" ennuste tilakohtaisesti. Tähän tarkoitukseen on ARTTURI ${ }^{\circledR}$-verkkopalvelussa käytettävissä Tilan räätälöity Darvolaskuri, johon määritetyn D-arvon ja näytteenottopäivän tallentamalla saa ennustemallilla lasketun arvion kasvuston D-arvosta näytteenoton jälkeen (Rinne ym. 2009).

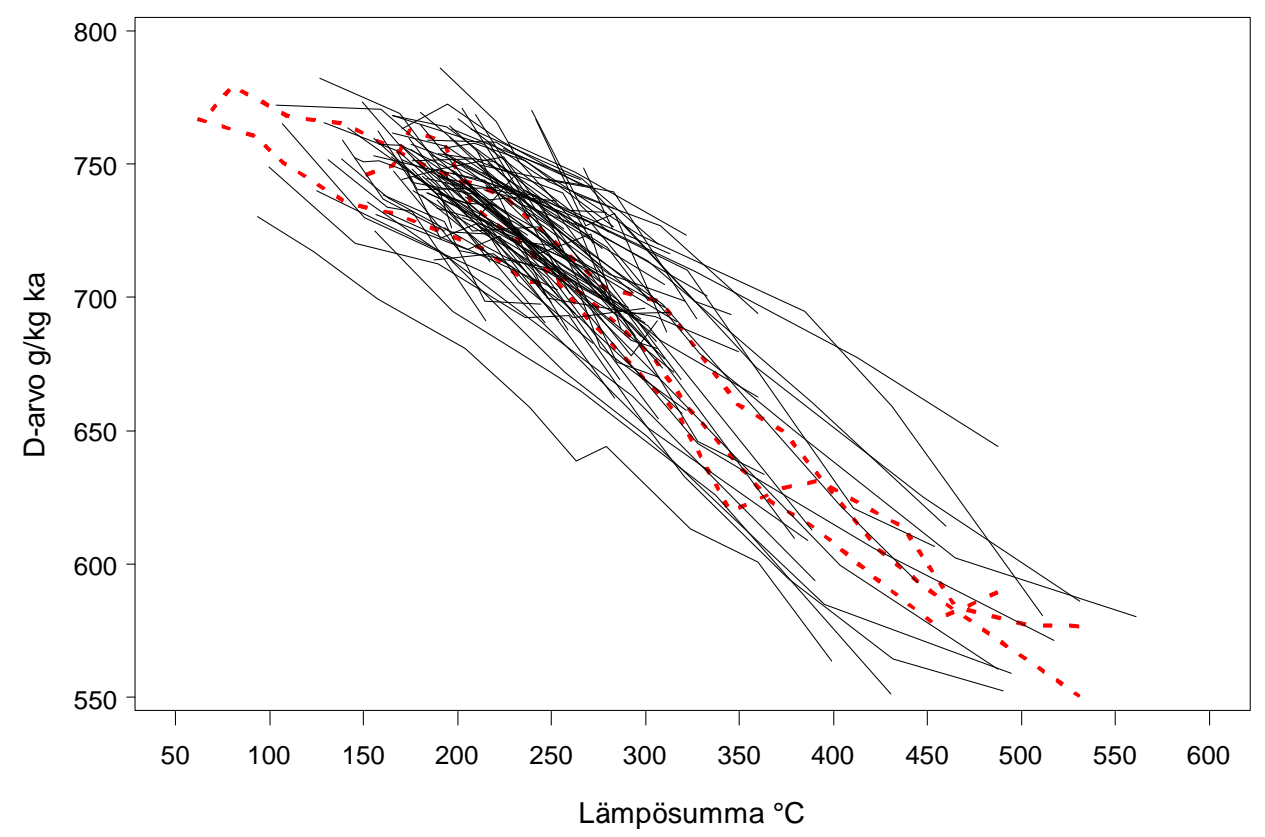

Kuva 3. Korjuuaika-aineiston D-arvon lasku lämpösumman kertyessä siten, että saman kasvuston havainnot on yhdistetty toisiinsa viivalla (näytteitä 430 ja sarjoja 101). Jokioisten ns. pitkät sarjat on merkitty kuvaan katkoviivalla.

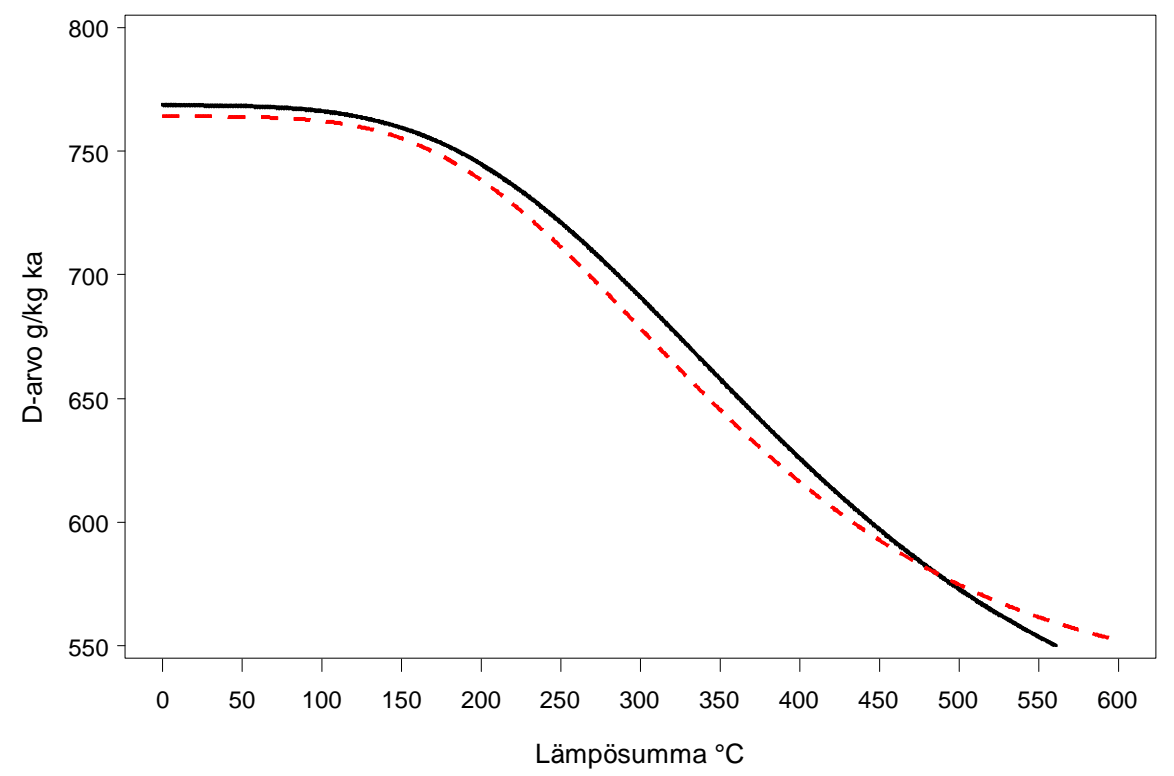

Kuva 4. Ennustemallin kuvaaja näyttää D-arvon kehityksen käyräviivaisuuden. Musta yhtenäinen viiva kuvaa koko aineistosta estimoitua keskimääräisen sarjan $D$-arvon kehitystä $\left(R^{2}=0.82\right)$ ja katkoviiva Jokioisilta mitattujen pitkien sarjojen avulla estimoitua kehitystä $\left(\mathrm{R}^{2}=0.97\right)$. 


\section{Kuiva-ainesato}

Kuiva-ainesatoa mallitettiin lineaarisilla sekamalleilla ja mallien vertailu on esitetty taulukossa 3 ja havainnot on esitetty kuvassa 5. Mallissa oli aina joko kasvukauden pituus tai lämpösumma satunnaisvaikutuksena riippuen mallin selittäjävalikoimasta. Kuiva-ainesadot hehtaaria kohden vaihtelivat välillä 500 kg - 11000 kg keskiarvon ollessa 4200 kg/. Kuiva-aineen hehtaarisato lisääntyi keskimäärin 191 kg/pv kasvun edetessä alkukesällä. Rinteen ym. (2007) luomunurmista kerätyssä nurmiheinien ja puna-apilan seoskasvustoja sisältävässä korjuuaika-aineistossa päivittäinen kuiva-ainesadon kertymä oli 214 kg/ha ja Kuoppalan ym. (2010) puhtaista puna-apiloista kerätyssä aineistossa 177 kg/ha eli samaa suuruusluokkaa. On huomioitava, että kaikki nämä aineistot perustuvat koelohkojen kehikkomittauksiin eli absoluuttiset havaitut sadot ja päivittäiset kasvun kertymät ovat systemaattisesti suurempia kuin talousviljelmien keskimäärin.

Lämpösumman "purkaminen” kasvupäiviin ja keskilämpötilaan kasvuaikana paransi hieman mallia. Ennen kasvukauden alkua kertyneen lämpösumman huomioiminen paransi tyypillisesti malleja eli kevään lämpöolosuhteet jo ennen kasvukauden alkua vaikuttavat kuiva-ainesadon kertymiseen. Virhe oli pienempi, kun lämpösummaa laskettiin 28 vrk ennen kasvukauden alkua verrattuna 14 vrk:en. Maalajin vaikutus ei ollut merkitsevä lämpösumman kanssa, mutta kun mallissa oli kasvupäivät ja keskilämpötila, olivat myös maalaji ja keskilämpötila×maalaji merkitseviä.

Ehkä hieman yllättäen sadesumma ei vaikuttanut merkitsevästi kuiva-ainesatoon. Ilmeisesti kuivuus ei valtakunnallisesti kovin merkittävästi rajoita nurmikasvien kasvua ensimmäisessä sadossa. Sadesumma ei myöskään ole kovin tarkka suure kuvaamaan maaperän kosteuspitoisuutta. Vaihtelut sadon määrän kasvussa ja kasvustojen väliset tasoerot olivat suuria joten kuiva-ainesatoennusteet voivat lohkokohtaisesti olla ainoastaan suuntaa-antavia.

Taulukko 3. Nurmikasvustojen kuiva-ainesadon (t/ha) ennustaminen lineaarisilla satunnaiskertoimisilla sekamalleilla. Tilastollisesti merkitsevät $(\mathrm{P}<0.05)$ selittäjät on lihavoitu.

\begin{tabular}{|c|c|c|c|c|c|c|c|c|c|c|c|c|c|}
\hline \multicolumn{5}{|c|}{ Selittäjät } & \multirow[b]{2}{*}{ Vakio } & \multicolumn{5}{|c|}{ Regressiokertoimet } & \multirow{2}{*}{$\mathrm{AIC}^{2)}$} & \multirow{2}{*}{$\begin{array}{l}\text { Hajon- } \\
\text { ta }^{3)}\end{array}$} & \multirow{2}{*}{$\mathrm{R}^{2}$} \\
\hline $\mathrm{X} 1^{1)}$ & $\mathrm{X} 2$ & X3 & $\mathrm{X} 4$ & $\mathrm{X} 5$ & & $\mathrm{X} 1$ & $\mathrm{X} 2$ & X3 & X4 & $\mathrm{X} 5$ & & & \\
\hline Kpv & & & & & -5.21 & 0.191 & & & & & 1042.8 & 0.462 & 0 \\
\hline Kpv & X lämpö & $\mathrm{X} 1 \times \mathrm{X} 2$ & & & -14.14 & 0.208 & 1.222 & -0.009 & & & 929.2 & 0.470 & 0.48 \\
\hline Kpv & X lämpö & & & & -10.02 & 0.119 & 0.829 & & & & 929.3 & 0.474 & 0.50 \\
\hline Kpv & X lämpö & Keskisade & $\mathrm{X} 1 \times \mathrm{X} 3$ & & -9.70 & 0.112 & 0.820 & -0.136 & 0.005 & & 931.9 & 0.476 & 0.50 \\
\hline Kpv & X lämpö & Keskisade & & & -10.02 & 0.119 & 0.816 & 0.092 & & & 930.4 & 0.475 & 0.50 \\
\hline Kpv & X lämpö & PreLS14 & & & -10.35 & 0.127 & 0.752 & 0.023 & & & 915.2 & 0.472 & 0.53 \\
\hline Kpv & X lämpö & PreLS28 & & & -9.69 & 0.132 & 0.703 & 0.009 & & & 913.3 & 0.465 & 0.52 \\
\hline Kpv & X lämpö & PreLS28 & Maalaji & $\mathrm{X} 3 \times \mathrm{X} 4$ & -9.61 & 0.132 & 0.702 & 0.010 & -0.137 & -0.001 & 916.4 & 0.464 & 0.52 \\
\hline Kpv & X lämpö & PreLS28 & Maalaji & $\mathrm{X} 2 \times \mathrm{X} 4$ & -8.29 & 0.133 & 0.563 & 0.009 & -2.369 & 0.226 & 911.9 & 0.459 & 0.51 \\
\hline LS5 & & & & & -1.20 & 0.021 & & & & & & 0.482 & 0.50 \\
\hline LS5 & PreLS14 & & & & -1.71 & 0.021 & 0.015 & & & & 35.1 & 0.481 & 0.53 \\
\hline LS5 & PreLS14 & Maalaji & yckm & $\mathrm{X} 3 \times \mathrm{X} 4$ & -1.68 & 0.021 & 0.014 & 0.341 & 0.041 & -0.166 & 935.4 & 0.481 & 0.54 \\
\hline LS5 & PreLS14 & Maalaji & yckm & & -1.51 & 0.021 & 0.014 & -0.019 & -0.064 & & 936.8 & 0.482 & 0.54 \\
\hline LS5 & PreLS28 & Maalaji & yckm & $\mathrm{X} 3 \times \mathrm{X} 4$ & -1.40 & 0.021 & 0.004 & 0.367 & 0.052 & -0.193 & 935.9 & 0.481 & 0.54 \\
\hline
\end{tabular}

${ }^{1)}$ Tämän selittäjän kulmakerroin ja vakiotermi olivat mallissa satunnaisia

${ }^{2)}$ Akaiken informaatiokriteeri - mitä pienempi, sitä parempi malli

${ }^{3)}$ Jäännösvirheen hajonta, $\mathrm{t} / \mathrm{ha}$ (residual)

Kpv = kasvupäivät kasvukauden alusta lähtien

Xlämpö = keskilämpötila näytteenottoon asti kuluneen kasvukauden aikana, ${ }^{\circ} \mathrm{C}$

Keskisade = keskimääräinen sademäärä näytteenottoon asti kuluneen kasvukauden aikana, mm/pv

PreLS14 = Kasvukauden alkua edeltävien 14 vrk:n keskilämpötilojen summa, ${ }^{\circ} \mathrm{C}$ vrk

PreLS28= Kasvukauden alkua edeltävien 28 vrk:n keskilämpötilojen summa, ${ }^{\circ} \mathrm{C}$ vrk

Maalaji = Kasvupaikan maalaji luokiteltuna lämpimiin (1) ja kylmiin (2)

LS5 = Lämpösummakertymä kasvukauden alusta näytteenottohetkeen, ${ }^{\circ} \mathrm{C}$ vrk

yckm = Y-koordinaatti, yksikkö 100km, nollapiste Ahvenanmaasta lounaaseen sijaitsevalla merialueella 


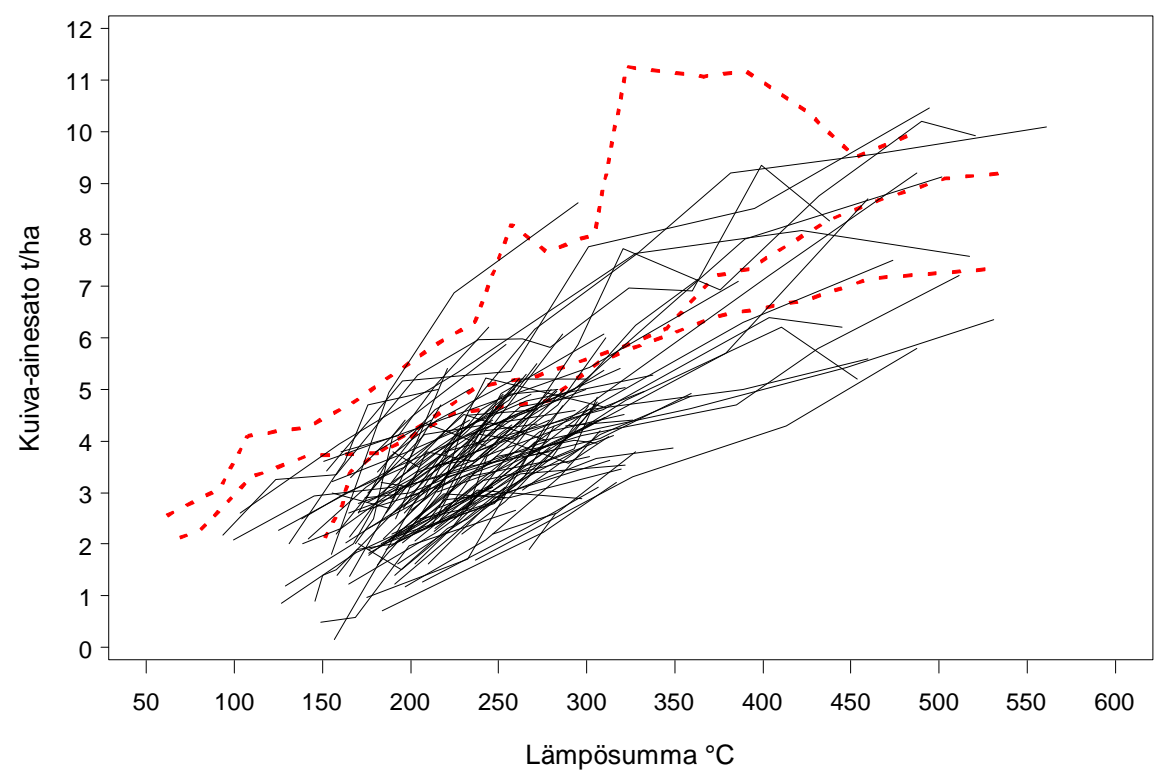

Kuva 5. Korjuuaika-aineiston kuiva-ainesadon kasvu lämpösumman kertyessä siten, että saman kasvuston havainnot on yhdistetty toisiinsa viivalla (näytteitä 430 ja sarjoja 101). Jokioisten ns. pitkät sarjat on merkitty kuvaan katkoviivalla.

\section{Johtopäätökset}

Nurmisadon D-arvon lasku alkukesällä on hyvin nopeaa ja varsin johdonmukaista. D-arvon muutos on käyräviivaista, mutta säilörehun korjuuaikaan sen on varsin lineaarista ja keskimäärin 5 g/kg ka päivässä. Lämpösummaa käyttäen D-arvon kehityksestä voidaan antaa kohtuullisia yleisiä ennusteita. Lämpö-olot vaikuttivat merkitsevästi myös kuiva-ainesadon kertymiseen, mutta sadesumma ei. Kasvustokohtaiset erot olivat erittäin suuria joten kuiva-ainesatoennusteet voivat olla ainoastaan suuntaaantavia.

\section{Kirjallisuus}

Artturi. 2009. ARTTURI® -verkkopalvelu. Viitattu 10.11.2009. www.mtt.fi/artturi.

MTT. 2006. Rehutaulukot ja ruokintasuositukset -verkkopalvelu. Viitattu 10.11.2009.

www.mtt.fi/rehutaulukot

Huhtanen, P., Nousiainen, J. \& Rinne, M. 2005. Prediction of silage composition and organic matter digestibility from herbage composition and pepsin-cellulase solubility. Agricultural and Food Science 14: 154-165.

Huhtanen, P., Nousiainen, J. \& Rinne, M. 2006. Recent developments in forage evaluation with special reference to practical applications. Agricultural and Food Science 15: 293-323.

Kuoppala, K., Rinne, M., Tuori, M. Pursiainen, P. \& Vanhatalo, A. 2010. Puna-apilakasvuston kehitysrytmi alku- ja loppukesällä. Maataloustieteen Päivät 2010, www.smts.fi.

Nousiainen, J., Rinne, M., Hellämäki, M. \& Huhtanen, P. 2003. Prediction of the digestibility of the primary growth of grass silages harvested at different stages of maturity from chemical composition and pepsin-cellulase solubility. Animal Feed Science and Technology 103: 97-111.

ProAgria. 2009. Lypsykarjan rehunkulutus ja tuotosseuranta 2008. Saatavilla Internetissä: http://www.proagria.fi/palvelut/maito/Tulosseminaari\%202008snluvut.pdf

Rinne, M. 2000. Influence of the timing of the harvest of primary grass growth on herbage quality and subsequent digestion and performance in the ruminant animal. University of Helsinki, Department of Animal Science. Publications 54. 42 p. + 5 encl. Saatavilla Internetissä: http://ethesis.helsinki.fi/julkaisut/maa/kotie/vk/rinne.

Rinne, M., Nykänen, A., Nyholm, L., Nousiainen, J. \& Vanhatalo, A. 2007. Kehitysrytmi huomioitava apilanurmen korjuussa. Puna-apilaa nurmiin ja ruokintapöydälle. Puna-apila tehokkaasti luomumaidoksi tutkimushankkeen päätösseminaari 17.4.2007. Toim. A. Vanhatalo \& M. Topi-Hulmi Suomen Nurmiyhdistyksen julkaisuja 25: 23-33. Saatavilla Internetissä:

https://portal.mtt.fi/portal/page/portal/nurmiyhdistys/Julkaisut/punaapila/rinne.pdf 
Rinne, M., Huhtanen P. \& Nousiainen, J. 2008a. Säilörehun ja koko rehuannoksen syönti-indeksit auttavat lypsylehmien ruokinnan suunnittelussa. Julkaisussa: Maataloustieteen Päivät 2008 [verkkojulkaisu]. Suomen Maataloustieteellisen Seuran tiedotteita no 23. Toim. Anneli Hopponen. Julkaistu 9.1.2008. Saatavilla Internetissä: http://www.smts.fi/mpol2008/index_tiedostot/Esitelmat/es086.pdf

Rinne, M., Huhtanen, P. \& Nousiainen, J. 2008b. Karkearehujen sulavuuden määritys tarkentunut. Julkaisussa: Maataloustieteen Päivät 2008 [verkkojulkaisu]. Suomen Maataloustieteellisen Seuran tiedotteita no 23. Toim. Anneli Hopponen. Julkaistu 9.1.2008. Saatavilla Internetissä:

http://www.smts.fi/mpol2008/index tiedostot/Posterit/ps024.pdf.

Rinne, M., Nyholm, L. \& Hellämäki, M. 2009. Artturi® valppaana kesään - Nurminäytteen perusteella lohkokohtainen D-arvoennuste. Maito ja Me 2/2009, s. 30-31.

Thornley, J.H.M. \& France, J. 2007. Mathematical Models in Agriculture: Quantitative Methods for the Plant, Animal and Ecological Sciences, 2nd Edition. CABI, Wallingford, UK, 906 s.

Vonesh, E. \& Chinchilli, V. 1997. Linear and nonlinear models for the analysis of repeated measurements. Marcel Dekker, Inc., New York, New York, 560s. 